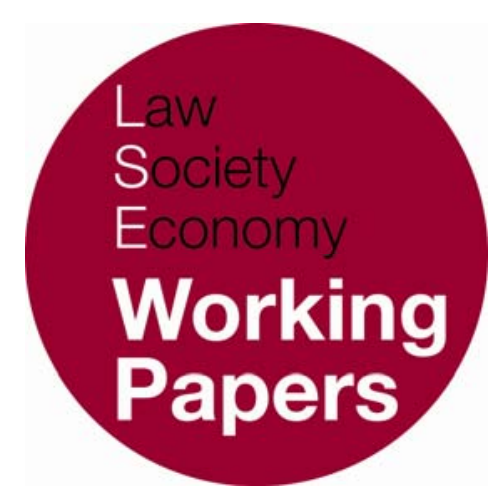

\title{
A Bill of Rights: do we need one or do we already have one?
}

\author{
Francesca Klug
}

LSE Law, Society and Economy Working Papers 2/2007 London School of Economics and Political Science Law Department

This paper can be downloaded without charge from LSE Law, Society and Economy

Working Papers at: www.lse.ac.uk/collections/law/wps/wps.htm and the Social Science Research Network electronic library at: http://ssrn.com/abstract $=999952$

(C) Francesca Klug. Users may download and/or print one copy to facilitate their private study or for non-commercial research. Users may not engage in further distribution of this material or use it for any profit-making activities or any other form of commercial gain. 


\title{
A Bill of Rights: do we need one or do we already have one?
}

\author{
Francesca Klug*
}

\begin{abstract}
The article asks whether the Human Rights Act can be described as a bill of rights. Concluding that the Act is effectively a Bill of Rights, it examines why there are calls to introduce a 'home-grown' Bill of Rights and why these proposals have surfaced now. Finally, it asks whether we can assume that such proposals would lead to better human rights protection, or whether it is possible to end up with less than we have now?
\end{abstract}

\section{INTRODUCTION}

'Take some more tea', the March Hare said to Alice. 'I've had nothing yet, so I can't take more' Alice replied. 'You mean you can't take less', said the Mad Hatter. 'It's very easy to take more than nothing.'

Inverting that Alice in Wonderland logic, how can the leader of the Conservative Party ${ }^{1}$, amongst a small but still growing chorus of commentators, ${ }^{2}$ activists ${ }^{3}$ and others, ${ }^{4}$ call for a bill of rights if we have one already? You can ask for a better bill of rights, or a stronger one, but you can't say 'we need a bill of rights' if there is one now.

\footnotetext{
* Francesca Klug, Professorial Research Fellow, Centre for the Study of Human Rights, LSE. With gratitude to Helen Wildbore for her excellent research assistance. This article is based on an address originally made at the Irvine Lecture 2007, Human Rights Centre, University of Durham, 2 March 2007, to be published in Public Law, Winter 2007.

1 Speech to Centre for Policy Studies, 26 June 2006. The Conservative Party have now announced the membership of their Bill of Rights Commission. Press Release, 28 March 2007.

2 See H. Porter, 'After a sinister year, it's down to us to protect our freedoms', The Observer, 31 December 2006.

3 'Rival Parties Unite to Fight for a Bill Of Rights', The Observer, 31 December 2006.

${ }^{4}$ It has occasionally been rumoured that Gordon Brown may also be considering supporting a British Bill of Rights. Eg. see A. Grice, 'Tory Leader is stealing Brown's best tunes', Independent, 30 September 2006.
} 
But do we have one now? If we don't already have a bill of rights, then as the Hatter said, it is very easy to have more than nothing. But is the Hatter truly mad to suggest that it is impossible to have less than nothing?

To address this conundrum I am going to try to answer three main questions. First, can the Human Rights Act fairly be described as a bill of rights? Second, why are there calls to introduce a 'home-grown' Bill of Rights and why now? Third, in spite of the Mad Hatter's dictum, would it be possible to end up with less than we have now?

\section{QUESTION 1: IS THE HRA A BILL OF RIGHTS BY ANY OTHER NAME?}

When the Human Rights Act (HRA) came into force in October 2000, the then Home Secretary, Jack Straw, described it as 'the first Bill of Rights this country has seen for three centuries'. ${ }^{5}$ He was not alone in giving it this description. Wikipedia lists the HRA under the heading of Important Bills of Rights alongside the American Bill and Canadian Charter of Rights, amongst others. The New York Times heralded the Act's arrival with the headline 'Britain Quietly Says it's Time to Adopt a Bill of Rights' commenting that, finally, 'ordinary Britons' will have a set of fundamental rights 'similar to those guaranteed by the [US] Bill of Rights'.

More seriously, Professor Philip Alston, the renowned international human rights lawyer, writing a year after the HRA was passed, cites the UK as one of a number of countries where there has been a 'proliferation of bills of rights in recent years'. ${ }^{6}$ I, myself, subtitled my book on the HRA, published by Penguin to coincide with its introduction in 2000, 'the story of the UK's new Bill of Rights'.

On what basis could, or should, the HRA be described as a Bill of Rights? Is this a political or a legal and constitutional description and is it a fair and reasonable one?

\section{Political BACKgROUND}

The introduction of the HRA followed years of debate about whether the UK should introduce a bill of rights and if so what kind? Nearly two hundred years to be precise.

The origins of this story can be traced to Tom Paine's Rights of Man, and the mounting panic of the British government that the French Revolution would prove contagious. When Paine published his best seller in 1791 he linked the struggle for democracy with the quest for fundamental rights, reproducing the French Declaration of the Rights of Man and Citizens in full. In his day, Paine electrified

5 Speech, Institute of Public Policy Research, 13 January 2000.

${ }^{6}$ P. Alston, Promoting Human Rights Through Bills of Rights: comparative perspectives (New York: Clarendon Press, 1999) 11. 
political debate in Britain. Within two years about a quarter of a million copies of Rights of Man were sold in a population of ten million. Social historian E.P. Thompson described the two-part pamphlet as the "foundation text of the English working-class movement'?

But the radical rights movement was not short of opponents. William Pitt's Whig government unleashed a purge against these 'seditious' ideas, encouraging the formation of societies in defence of 'the glorious constitution of old England'. 8

Condemnation and ridicule were not confined to the state or to the right. The liberal utilitarian, Jeremy Bentham, famously described the idea of inalienable rights as 'nonsense upon stilts'. ${ }^{9}$ Karl Marx notoriously dismissed 'the so-called rights of man'. 10

By the twentieth century Paine was eclipsed as a leading thinker for the labour movement by social democrats and Marxists who championed public ownership over constitutional reform and collective bargaining over individual rights.

Interest in the case for a Bill of Rights remained largely dormant until 1968 when Britain's famously 'unwritten' constitution came under renewed scrutiny after the Labour government's Commonwealth Immigrants Act was passed in only three days amidst a tabloid frenzy. The Act prevented British Asians expelled from East Africa from entering the UK, precisely at the time that they most needed their British citizenship. The expelled East African Asians were eventually vindicated by the European Court of Human Rights (ECtHR). But the European Convention on Human Rights (ECHR) was not enforceable in the domestic courts. Without a bill of rights or written constitution to turn to, British democracy offered these citizens virtually no protection from a government determined to bow to the 'will of the majority,' judged through the prism of the tabloid press.

Yet the bulk of the Tory and Labour parties remained un-persuaded about the benefits of constitutional reform. ${ }^{11}$ Conservative opinion tended to dismiss Bills of Rights as lethal for the doctrine of 'parliamentary sovereignty,' which was supported as an article of faith by advocates of the status quo.

Hailing from the constitutional settlement of 1688, which led to the first English Bill of Rights, this doctrine was interpreted as preventing any restraints on the 'will of the legislature' that would lead to one parliament binding its successor. The idea that certain laws touch on values that are so fundamental to democracy that they could have a higher moral claim over all others, was deemed largely alien to Britain's political and legal traditions.

Opposition from the left was more political than constitutional, although it largely amounted to the same thing. It centred on the concern that a judicially

\footnotetext{
${ }^{7}$ Quoted by E. Foner, in his Introduction to T. Paine, Rights of Man (London: Penguin Books, 1985) 18.

8 J. Keane, Tom Paine, a political life (London: Bloomsbury, 1995) 335.

9 J. Bowring (ed), The Works of Jeremy Bentham, Vol II (Edinburgh: William Tait, 1838) 501.

10 K. Marx, 'On the Jewish Question' (1843, first published February, 1844 in Deutsch-Franæösische Jabrbücher).

${ }^{11}$ Exceptions included Roy Jenkins, Shirley Williams, Sir Keith Joseph, Sir Michael Havers, Leon Brittain and Lord Hailsham.
} 
entrenched' bill of rights would inevitably undermine the capacity of left wing governments to carry through their programmes - such as limiting the powers of multinationals or the privileges of private schools - by empowering unaccountable judges to overturn laws deemed unconstitutional.

Support for a bill of rights in the UK remained largely the preserve of liberals (with an upper and lower case L). Lawyers dominated the campaign, ${ }^{12}$ such as it was, calling for a bill of rights based on the ECHR on the grounds that the government was already bound to comply with its terms.

It is a little known fact, however, that the Tories were elected on a manifesto in 1979 committing Margaret Thatcher's government to holding all-party discussions on a bill of rights. Once in power this commitment was air brushed out of political discourse. But it was 18 years of Conservative rule that was to turn the tide in the Labour Party in favour of constitutional reform. The reputation of the legislature as a bulwark against the government was pretty much in tatters. Parliamentary sovereignty was exposed as executive sovereignty in all but name. From the poll tax to the Spycathcher ban, the failure of the political system to mount a successful challenge to a mainly unpopular government became selfevident. On the basis of three elections won on a minority of the popular vote, the Conservatives demonstrated that they could enact any measures they wished. Then, as now, judges developed a reputation for being the only source of effective opposition to the government.

When the late Labour leader, John Smith, committed his party to support a British Bill of Rights in February 1993 it was as part of a package of proposals to 'restore democracy to our people - for what we have in this country at the moment is not real democracy; it is elective dictatorship'. ${ }^{13}$ Smith concluded that 'the quickest and simplest way' of introducing 'a substantial package of human rights' would be to pass a Human Rights Act 'incorporating into British law the European Convention on Human Rights, ${ }^{14}$ which the government, but not the courts, had been bound by since the post-war Atlee government ratified the ECHR in 1951.15

The 1993 Labour Conference adopted a Statement, introduced by the shadow home affairs spokesperson, supporting an all-party Commission to 'draft our own Bill of Rights', following the incorporation of the ECHR into UK law. ${ }^{16}$ The 1997

\footnotetext{
12 Notably Anthony (now Lord) Lester QC and the late judge Lord Scarman who in 1974 delivered his first Hamlyn Lecture on the case for a bill of rights.

13 'A New Way Forward', Speech, John Smith, Leader of the Labour Party, Bournemouth, 7 February 1993. The term 'elective dictatorship' was coined by the late Tory Lord Chancellor, Lord Hailsham, in his critique of the former Labour government.

14 'A Citizen's Democracy', Charter 88, March 1993. The IPPR published A British Bill of Rights in 1990 drafted by Anthony Lester QC and others based on the ECHR and the UN's International Covenant on Civil and Political Rights.

${ }^{15}$ It was the Atlee government that ratified the ECHR in 1951 and the Wilson government in 1966 that granted individuals the right to directly petition the European Court of Human Rights in Strasbourg.

16 'A new Agenda for Democracy: Labour's proposals for constitutional reform' NEC 1993.
} 
manifesto reflected the second part of this commitment and the Human Rights Act was introduced the following year.

It was soon obvious that ministers had lost any appetite they might have once had for following this up with a 'second stage' bill of rights. A commitment to a Northern Ireland Bill of Rights in the context of the peace process was included in the 1998 Good Friday agreement. Nearly ten years on, it is still being consulted upon under the auspices of the Northern Ireland Human Rights Commission in consultation with the all-party Bill of Rights Forum. ${ }^{17}$ For the rest of the UK it became evident early on that the introduction of the HRA more than exhausted the government's appetite for fundamental rights legislation.

\section{LEGAL AND CONSTITUTIONAL ISSUES}

Yet in reality, largely because the 'bill of rights debate' provided the original impetus for the HRA, it was drafted to be more than an incorporated treaty. As Labour's 'second stage bill of rights commitment' receded, so there was a push to draft the HRA 'in lieu' of a bill of rights.

Bills of Rights are rather strange creatures. They are not like any other legislation. Part symbolism, part aspiration and part law, they are fundamentally a set of broadly expressed entitlements and values. As a result they are open to wide and varied interpretations. Their impact depends on many factors outside the formal terms in which they are written.

Dictionary definitions provide little or no help in the search for the essential characteristics of a bill of rights. I personally prefer this one from the renowned early $20^{\text {th }}$ century American journalist, Frank I Cobb, 'The Bill of Rights is a born rebel. It reeks with sedition. In every clause it shakes its fist in the face of constituted authority.'

Professor Alston, the internationally renowned bill of rights expert, cautions against a rigid definition. He avoids the tautological contortions of some bills of rights advocates and scholars for whom a bill of rights which is not judicially entrenched' - in the sense of granting the courts the power to strike down legislation deemed to breach its terms - is no bill of rights at all.

On this definition the New Zealand Bill of Rights is a fraud; the bills of rights modelled on the UK Human Rights Act emerging in some Australian states and territories are charlatans ${ }^{18}$; and the Canadian Charter of Rights, with its parliamentary procedure for safeguarding legislation from judicial interference, is of dubious pedigree. It is worth pointing out that even the American Bill of Rights contains no power of judicial strike down; this was a power the courts took for

17 The Northern Ireland Human Rights Commission was mandated to consult on supplementary rights for Northern Ireland which 'together with the ECHR' would 'constitute a Bill of Rights for Northern Ireland' but there have been no steps by the government to introduce one.

18 The Australian Capital Territory passed a HRA in March 2004 largely modelled on the HRA and the State of Victoria has just introduced a 'Charter of Rights and Responsibilities' also based on the British model. 
themselves 16 years after the American Constitution was drafted, in the celebrated case of Marbury v Madison. ${ }^{19}$

Surveying the literature on bills of rights across the globe, Alston nevertheless points to three common characteristics:

i) They provide protection for those human rights which are considered, at a given moment in history, to be of particular importance.

ii) They are binding upon governments and can only overridden with significant difficulty. (Alston avoids the phrase 'judicial entrenchment' and does not exclude the possibility they can be overridden).

iii) They provide some form of redress in the event that violations occur. ${ }^{20}$

All these characteristics, I would maintain, co-exist to some degree in the HRA.

\section{i) Protection of significant rights}

As with most post-war bills of rights, the HRA draws its inspiration and principles from the 1948 Universal Declaration of Human Rights and the broad, ethical values it proclaims, aimed at establishing fair and tolerant societies. ${ }^{21}$ This is explicit in the preamble to the ECHR, most of whose rights are incorporated in the HRA. ${ }^{22}$

As such, the HRA does indeed uphold a swathe of the fundamental rights considered at this point in time to be important - the first of Altson's defining characteristics. Although, admittedly, the ECHR lags behind some of the more recent human rights instruments; for example, in its characterisation of equality and in its neglect of children's rights.

Typically, as Lord Hope acknowledged in Kebeline, ${ }^{23}$ most of the rights in the HRA can be legitimately and proportionately limited to protect other rights or interests, so that the Act has to be interpreted generously and purposefully to reflect its general spirit, ${ }^{24}$ rather than narrowly and literally. In this sense, the HRA is a different species than the technical, 'black letter' law characteristic of most British statutes. It contains the hallmark of broadly expressed, open textured values that distinguish bills of rights from specific legislation which rely on a literal interpretation of the precise words used.

Crucially, however, British courts can develop their own interpretation of the broad values in the HRA, provided this does not 'weaken' the protection afforded

195 U.S. 137 (1803).

$20 \mathrm{n} 6$ above, 10

${ }^{21}$ The 1948 UDHR was a direct response to the horrors of the Holocaust and Wold War Two.

22 The ECHR gives legal expression to most of the civil and political rights in the UDHR, as its preamble makes clear.

${ }^{23} \mathrm{R}$ (Kebeline) v DPP [1999] 3 WLR 972.

${ }^{24}$ See, for e.g. Case 4451/70, Golder v UK (1975), [1979-80] 1 E.H.R.R. 524. 
by the ECHR. ${ }^{25}$ This capacity is an essential hallmark that distinguishes the HRA from an incorporated treaty typical of monist systems, of which there are many in Europe, where ratification of a treaty automatically binds the national authorities, including the courts, to comply with its provisions. Contrary to recent, misleading statements by the Leader of the Conservative Party that the HRA 'obliged British courts to base their judgements on the ECHR and [its] case law...giving them no scope to develop their own principles'26, Judges are required under section 2 of the HRA to 'take account of' the European Court case-law, but are not bound by it.

It was, in fact, the Conservative front bench who tabled amendments in the House of Lords, during the passage of the HRA, aimed at binding the domestic courts to Strasbourg jurisprudence. These were rejected by Lord Irvine, then Lord Chancellor, on the grounds that 'there may...be occasions when it would be right for the UK courts to depart from Strasbourg decisions' such as where judgements were 'given decades ago'. ${ }^{27}$ Irvine hopes that 'our courts' would 'give a lead to Europe as well as...[be] led'. ${ }^{28}$

As Conservative MP, Edward Leigh, rightly observed at the time, once our courts are given that freedom, "we are in danger of not simply incorporating the convention in our law but going much further. What we are creating is an entirely new bill of rights'. ${ }^{29}$

Recently, however, the courts have started to row back on Parliament's intention to allow them to develop their own jurisprudence under the HRA. There has been a series of such cases since Lord Bingham pronounced in Ullab that 'the duty of the national courts is to keep pace with the Strasbourg jurisprudence as it evolves over time: no more, but certainly no less. ${ }^{30}$ Whilst it is possible to agree with the 'no less' stipulation, why no more? LJ Buxton consciously and explicitly departed from the Strasbourg decision in $S v U K,{ }^{31}$ for example, to provide protection for homosexual partnerships in Ghaidan v Mendoza. ${ }^{32}$

As legal academic, Roger Masterman, has pointed out, the Convention itself 'assumes that the domestic courts will also take a progressive approach' to rights

${ }^{25}$ S 2 of the HRA. Recently, however, the courts have started to interpret this section as if it required the courts to stay within the confines of the case law of the Strasbourg court. See R (Ullab) v Secretary of State for the Home Department [2004] UKHL 26 and R (Al-Jedda) v Secretary of State for Defence [2006] EWCA Civ 327. This was not the original intention behind the HRA, one of whose stated aims was to influence Strasbourg jurisprudence via the interpretations that might be put on it by British courts, a development which has started to occur in practice.

26 British Bill of Rights, Centre for Policy Studies, 26 June 2006.

${ }^{27}$ HL Deb vol 584 col 127119 January 1998.

${ }^{28}$ HL Deb vol 583 col 51518 November 1997.

${ }^{29}$ HC Deb vol 313 col 3983 June 1998.

${ }^{30} \mathrm{R}$ (Ullab) v SS Home Dept [2004] UKHL 26 at [20]. See also R (Countryside Alliance) v HM Attorney General [2006] EWCA Civ 817; R (Clift v SSHD) [2006] EWCA Civ 817.

31 (1986) 47 D\&R 247.

32 Ghaidan v Mendoza [2004] UKHL 30. See also R (LS and Marper) v Chief Constable of South Yorkshire Police, [2002] EWCA Civ 1275 at [34]. 
and should be 'free to develop an enhanced protection within their national legal system'.33

This argument is given force by the 'margin of appreciation' doctrine which means there are many issues on which there is no persuasive Strasbourg authority at all. Sir Andrew Morritt VC got to the heart of the matter when he said in Aston Cantlow that the judges task: 'is not to cast around in the European Human Rights Reports like black letter lawyers seeking clues. In the light of section 2(1) of the HRA, it is to draw out the broad principles which animate the Convention. ${ }^{34}$

This approach is what distinguishes the HRA from an incorporated treaty. It is what places it in the realm of a bill of rights that take its source from a regional human rights treaty but is interpreted by domestic judges, who also draw from the human rights jurisprudence of other jurisdictions where appropriate. ${ }^{35}$ As human rights Professor Robert Wintemute has commented, if a country voluntarily incorporates the exact wording of the Convention into its national law, the Convention ceases to be a European text and becomes a national text, to which national courts are free to give a more generous interpretation'. ${ }^{36}$

\section{ii) Binding the executive}

Alton's second indicator - that bills of rights should be binding on the executive is another defining principle of the HRA. Governments, like the courts and all public authorities, are explicitly prohibited from acting incompatibly with the rights it upholds. The HRA is the only domestic statute (excluding the European Communities Act) that is determinative of future legislation, as well as past, and it is governments, of course, that are the prime initiator of laws.

There is, as is well established, a significant caveat to this requirement under the Act. Whilst exhibiting many features of a 'higher law' to which all other laws and policies must conform where 'possible', 37 the HRA prohibits courts from striking down Acts of Parliament. Judges can declare Acts incompatible with the rights in the HRA under section 4, but it is a decision for Parliament, or more

33 R. Masterman, 'Taking the Strasbourg Jurisprudence into Account: developing a 'municipal law of human rights' under the HRA' (2005) 54 ICLQ 907, 911. See also E. Wicks, 'Taking Account of Strasbourg? The British Judiciary's Approach to Interpreting Convention Rights' (2005) 11 European Public Law 405.

34 Parochial Church Council of Aston Cantlow and Wilmcote with Billesley v Wallbank, [2001] 3 WLR 1323 at [44].

${ }^{35}$ For example, in Wilkinson v Kitzinger and Attorney General [2006] EWHC 2022 (Fam), where a declaration was sought that a same sex marriage which took place in Canada was a valid marriage in English law, the court referred to laws in other jurisdictions on same sex marriage. In $\mathrm{R}$ (Begum) v Denbigh High School [2006] UKHL 15, the House of Lords found no interference with a girl's Article 9 rights where she missed two years of school because she refused to observe the uniform policy. The court refers to a decision of the South African Constitutional Court which had explained the fundamental importance of the Article 9 right in a pluralistic, multi-cultural society.

${ }^{36}$ R. Wintemute, ‘The Human Rights Act's First Five Years: too strong, too weak or just right?’ (2006) 17 Kings College Law Journal 209.

${ }^{37} \mathrm{~s} \mathrm{3}$ (1) states 'so far as it is possible to do so primary and subordinate legislation must be read and given effect in a way which is compatible with Convention rights.' 
realistically government, whether, and if so how, to proceed. The executive is not legally bound by the HRA when a Declaration of Incompatibility (DOI) has been issued.

Lord Hope, in Shayler, correctly stated that where legislation cannot be interpreted to remove an incompatibility under section 3 of the HRA, 'the position whether it should be amended so as to remove the incompatibility must be left to Parliament' and the only option left to the courts is to issue a DOI. 38

In reality, however, the government has never ignored such Declarations. Of the 16 DOIs issued by the higher courts and still standing (out of 22 made altogether) the government has responded either by amending, or committing to amend, the legislation or policy at issue, or changing the offending practice. ${ }^{39}$ They might refuse to do so in the future, but this is likely to be far from usual.

And whilst it is quite true that Parliament can still theoretically pass any domestic legislation it wishes (exempting EU-driven law and subject to the censure of the ECtHR) breaches of fundamental rights have become far more transparent, as we are seeing with the current tussles over control orders. ${ }^{40}$ Ministers are now statutorily bound to declare whether Bills they introduce respect fundamental rights and the courts are constitutionally empowered to review Acts of Parliament for the first time in British history.

With the establishment of the increasingly authoritative parliamentary Joint Committee on Human Rights, ${ }^{41}$ whose self-defined remit now includes evaluating government responses to DOIs, the executive, legislature and judiciary each have a role in rights compliance. They are effectively engaged in a dialogue about the nature of human rights and how they should be applied, as Jack Straw predicted

38 [2002] 2 WLR 754 at [53].

39 To date, 22 DOIs have been issued by the Higher Courts of which 16 are still standing and 6 overturned on appeal. The Government has yet to respond to the two most recent Declarations ( $R$ (Wright et al) v Secretary of State for Health and Secretary of State for Education and Skills [2006] EWHC 2886 and $R$ (Clift et al) v Secretary of State for the Home Department [2006] UKHL 54) and in two other cases the government is still considering how to remedy the incompatibility ( $\mathrm{R}$ (Morris) v Westminster City Council e First Secretary of State [2005] EWCA Civ 1184 and R (Gabaj) v First Secretary of State 28 March 2006, unreported).

40 The Court of Appeal held that the control orders imposed on a group of Iraqi and Iranian asylum seekers who were detained to be deported on national security grounds and then subjected to nonderogating control orders under s 2 of the Prevention of Terrorism Act 2005, amounted to a deprivation of liberty contrary to Article 5 of the Convention. The control orders required them to remain in a one bedroom flat for 18 hours per day, to be electronically tagged at all times and prevented them from going outside a defined area around their residences, among other restrictions. The court held that the purported 'non-derogating control orders' made by the secretary of state were, in fact, 'derogating control orders' that the secretary of state had no power to make and the lower court had been right to quash the orders. The government responded by issuing new orders, subjecting the men to less restrictive conditions, but lodged an appeal at the House of Lords. Secretary of State for the Home Department $\mathrm{v} J J$ and others [2006] EWCA Civ 1141.

${ }^{41}$ See F. Klug, 'The Klug Report: Report on the Working Practices of the JCHR', published in 'The Committee's Future Working Practices', Twenty-third Report of Session 2005-06, HL Deb vol 239, HC Deb vol 1575. 
they would be when piloting the Human Rights Bill through Parliament nearly 10 years ago. 42

It is wrong to assume, as some constitutional lawyers do, that this approach to rights compliance, sometimes referred to as the 'dialogue model', ${ }^{43}$ was introduced solely to protect the doctrine of parliamentary sovereignty and hence retain the ultimate authority of government. It was adopted partly for this reason but also to address the perceived 'democratic deficit' characteristic of bills of rights with judicial strike down powers, notably in the USA, South Africa and Germany. In these jurisdictions the power to determine the meaning of broad values like liberty or privacy - and to re-write or repeal laws which don't conform to that meaning are handed from elected politicians to unaccountable judges who effectively become legislators in the process.

The 'dialogue model' was a response to this stumbling block to support for bills of rights within the Labour Party, which, as we saw, was largely sceptical about handing judges the power to strike down legislation and so hamper the policies of a future labour government. The model reflected a considered view, given clear expression by Geoffrey Palmer, the former New Zealand Minister of Justice, in the White Paper that heralded the 1990 New Zealand Bill of Rights, that 'in a great many cases where controversial issues arise... there is no 'right' [human rights] answer'. ${ }^{4}$

Many of us who were involved in the campaign for a bill of rights in the early 1990s held the view that the interpretation of broad values inherent in all bills of rights - such as the right to life or the legitimate limits of free speech - often involves philosophical or quasi-political judgement that are better determined by elected representatives, with the courts acting as a check on the executive, rather than as a primary decision taker or law maker.

Jack Straw emphasized from the outset that higher courts 'could make a Declaration [of Incompatibility] that, subsequently, Ministers propose and Parliament accepts, should not be accepted.' 45 The example he gave was abortion law, but he might have added advertising restrictions, gun controls and election expenditure limits, ${ }^{46}$ all issues that courts with strike down powers in other jurisdictions have determined breach their bills of rights. ${ }^{47}$

\footnotetext{
${ }^{42}$ Jack Straw described the HRA model in the following terms: 'Parliament and the judiciary must engage in a serious dialogue about the operation and development of the rights in the Bill...this dialogue is the only way in which we can ensure the legislation is a living development that assists our citizens' HC Deb vol 314 col 114124 June 1998.

43 See F. Klug 'The Long Road to Human Rights Compliance' (2006) 57 Northern Ireland Legal Quarterly, Special Issue: Human Rights and Equality 186 and n 40 above.

${ }^{44}$ A Bill of Rights for New Zealand; White Paper, 1985.

${ }^{45}$ HC Deb vol 317 col 130121 October 1998. My emphasis. Lord Hope, confirmed this in the case of R $v$ Shayler [2002] UKHL 11 at [53] when he said decisions as to 'whether [offending legislation] should be amended...must be left to Parliament.' My emphasis.

46 Constitutionally speaking, there was no obligation on the government to comply with the Belmarsh indefinite detention ruling either (see note 49 below) although realistically the European Court of Human Rights was likely to take a similar approach to the domestic courts on this issue.

${ }^{47}$ Notably in the USA.
} 
As my colleague Professor Conor Gearty has put it, 'the genius of the HRA' model invites 'the political back in to control the legal at just the moment when the supremacy of the legal discourse seems assured'.48

The fact that Parliament (or more accurately, the government acting through Parliament) still has 'the final say,' under the HRA should not be confused with 'business as usual.' The HRA clearly refines - though does not overturn - the doctrine of 'parliamentary sovereignty,' as successive Home Secretaries have volubly complained. Governments and Parliament are now accountable for their actions to a set of internationally recognised human rights values enshrined in the HRA, which they can no longer ignore with impunity, using the will of the electorate as 'cover.' Alston's qualification, that it should only be possible to override a bill of rights 'with difficulty,' applies to the HRA.

\section{iii) Redress for violations}

Alton's third defining feature - redress for rights violations - is also present in the HRA. The Act provides everyone within the jurisdiction of the UK with a set of fairly simple, written rights that they can use to hold public authorities to account; inside or outside the courtroom.

Remedies are available, at the discretion of the courts, where unjustified breaches occur. Of course there are many people who have been disappointed by the outcome of their cases under the HRA, as with all bills of rights. Failing to heed the warning of the eminent human rights professor, David Feldman, that 'Convention rights are unlikely to operate in a purely liberal and individualistic way', there were numerous early cases that confounded the expectations of both the opponents and proponents of the HRA. ${ }^{49}$

But there is now a growing list of people who have benefited, when prior to the HRA they would have had no remedy at all - from the Belmarsh detainees who were subject to indefinite detention without trial ${ }^{50}$ to disabled people subject to undignified treatment in their own home. ${ }^{51}$ The courts have applied their duty

${ }^{48}$ C. Gearty, Can Human Rights Survive? (Cambridge: Cambridge University Press, 2006) 95.

49 D. Feldman, 'The HRA 1998 and Constitutional Principles' (1999) 19 Legal Studies 165, 173. See for example, Brown v Procurator Fiscal and Advocate General for Scotland [2001] 2 WLR 817 concerning the right against self-incrimination; Clingham v Kensington and Chelsea LBC [2002] UKHL 39 concerning the use of hearsay evidence in applications for anti-social behaviour orders; R ( $L S$ and Marper) v Chief Constable of South Yorkshire Police [2004] UKHL 39 concerning the retention and use by the police of DNA samples and fingerprint evidence after a suspect has been cleared of an offence.

50 A v Secretary of State for the Home Department [2004] UKHL 56. A were all foreign nationals who had been certified by the secretary of state as suspected international terrorists under the Anti-terrorism, Crime and Security Act 2001 s 21 and detained under s 23 of that Act without charge or trial.

51 Bernard v Enfield London Borough Council [2002] EWHC 2282 (Admin). Mrs Bernard, who was severely disabled and wheelchair bound, was housed in inappropriate and inadequately-adapted local authority accommodation (in effect confined to ground floor lounge) for 20 months after a Social Services Care Plan had stated that she needed urgently to move to a suitable adapted property. $R$ ( $A$ and $B$ ) v East Sussex County Council [2003] E.W.H.C. 167 (Admin) Two young women who suffered profound physical and learning disabilities and greatly impaired mobility challenged their local authority's policy of not permitting care staff to lift them manually. 
to interpret all policy and legislation compatibly with Convention rights where 'possible' (under section 3) to 'read down' what the courts considered to be overbroad legislation ${ }^{52}$ or re-interpret restrictive provisions to provide new safeguards. ${ }^{53}$

Admittedly, the European Court of Human Rights (ECtHR), in a number of post-HRA cases, has cast doubt on the effectiveness of the Declaration of Incompatibility as a remedy for breaches of Convention rights in the context of Article 35 of the ECHR, which requires applicants to exhaust all domestic remedies before the Court will deal with a complaint. ${ }^{54}$ However this perception appears to be changing. In a recent case, the Court speculated that 'at some future date evidence of a long-standing and established practice of ministers giving effect to the courts' declarations of incompatibility might be sufficient to persuade' it of 'the effectiveness' of DOIs as a remedy. 55

This should anyway not be confused with the broader debate about the adequacy of the HRA as a bill of rights; the ECtHR has made it clear that there is no obligation on member states to incorporate the ECHR into domestic law at all, ${ }^{56}$ let alone introduce any kind of bill of rights.

Of course most court challenges involve decisions and actions not legislation. Whereas before the HRA ministers, officials and others carrying out public functions could be challenged only if they acted so 'irrationally' they should probably have been sectioned anyway, they can now be held to account for breaching fundamental rights. When the banning of gay officers from serving in the military was declared rational and therefore lawful, although a clear breach of Convention rights, in the celebrated 1996 case of Smith, ${ }^{57}$ this was the final nail in the coffin of the ancient - and somewhat irrational in itself - regime.

Now, even the application of the common law is being reinterpreted to protect basic rights that were previously 'undiscovered,' as Prince Charles has demonstrated by successfully suing the Mail on Sunday for breach of confidence in his bid to protect his private life..$^{58}$ From pauper to prince, quite literally, everyone in the UK can potentially benefit from the HRA when no other remedy will apply. As Jack Straw once suggested, the HRA, on this reckoning, is indeed a bill of rights by any other name.

\footnotetext{
${ }^{52}$ For example, $\mathrm{R} v A$ (No. 2) [2001] 3 All ER 1 which read down what the court considered to be overbroad legislation affecting fair trial provisions and Attorney-General's Reference No.4 of 2002 [2004] UKHL 43 where s 11(2) of the Terrorism Act 2000 was read down using s 3 HRA so as to impose an evidential instead of a legal burden (s 11(2) provides a defence to the offence of belonging or professing to belong to a proscribed organisation).

${ }^{53}$ For example, $R$ v Offen [2001] 1 W.L.R. 253 which concerned mental health detainees and Ghaidan v Godin-Mendoza [2004] UKHL 30 which used s 3 to provide equal protection for homosexual tenants.

${ }^{54}$ Hobbs v UK (2002); BerL v UK (2004); Pearson v UK (2004).

55 Burden $\mathrm{v} U K$ (ECtHR, 12.12.06).

${ }^{56}$ Goodwin v UK, (2002); Vilrajah v UK (1991).

${ }_{57} \mathrm{R} v \mathrm{v}$ Ministry of Defence exp Smith [1996] 1 All ER 257.

${ }^{58}$ HRH Prince of Wales v Associated Newspapers Ltd [2006] EWCA Civ 1776.
} 


\section{QUESTION 2: SO IF THE HRA IS EFFECTIVELY A BILL OF RIGHTS WHY ARE THERE GROWING CALLS TO INTRODUCE ONE AND WHY NOW?}

For those lawyers and critics for whom a bill of rights is only a bill of rights if it is judicially entrenched, or given extra protection through a written constitution or special parliamentary majority, ${ }^{59}$ the HRA is, like a tribute band, by definition a poor relation of the 'real model.'

The renowned constitutional theorist, Geoffrey Marshall, for example, has dismissed the HRA as not a 'genuine Bill of Rights'. ${ }^{0}$ The barrister Tom Hickman has described it as 'legal aesthetics' not 'constitutional justice'. ${ }^{61}$

Legal academic Nicholas Bamforth, on the other hand, whilst not claiming 'special constitutional status' for the HRA, nonetheless concedes that it has 'a special constitutional role', in so far as section 3 lays down overriding and general rules of statutory interpretation. ${ }^{62}$ Judges in a number of cases have commented similarly, most recently when Lord Bingham marked on the 'constitutional shift' 63 introduced by the recognition of a right to freedom of assembly in the HRA, a right once declared missing from 'our constitution' by the famous $19^{\text {th }}$ century legal theorist, A.V. Dicey. ${ }^{64}$

My former colleague at King's College law school, Professor Wintemute, also concedes that 'the HRA is de facto a domestic bill of rights', whilst lamenting the absence of a judicial strike down power. ${ }^{65}$

But sadly or not this debate does not turn on the views of constitutional lawyers. Bills of rights are not just legal and constitutional documents. They have a symbolic role in highlighting the fundamental values that signify that a country stands for. They are intended to act as a baseline of common principles in a diverse society.

Assessed against these criteria, the HRA has clearly failed to pass muster. Support for introducing a bill of rights, at nearly $80 \%$, has remained fairly consistent over the last 15 years, according to the ICM 'State of the Nation' polls; the inference being that the HRA is generally not considered to be one. ${ }^{66}$ The reality

\footnotetext{
${ }^{59}$ Usually a requirement of support by two thirds of the legislature (both houses) before amendment or repeal.

${ }^{60}$ G. Marshall ‘Two Kinds of Compatibility: more about s3 of the HRA 1998’ P.L. 1999, Autumn, 377.

${ }_{61}$ T.R. Hickman ‘Constitutional Dialogue, Constitutional Theories and the HRA 1998' P.L. 2005 Summer 306.

${ }^{62}$ N. Bamforth 'Same-sex Partnerships: some comparative constitutional lessons' (2007) E.H.R.L.R., 1, 47.

${ }^{63}$ A phrase first employed by Justice Sedley in Redmond-Bate v DPP (2000) HRLR 249.

${ }^{64} \mathrm{R}$ (Laporte) v Chief Constable of Gloucestershire [2006] UKHL 55

65 n 35 above.

66 A YouGov Survey commissioned by the Disability Rights Commission in June 2006 found that $62 \%$ of respondents thought it was good to have an Act to protect everyone's rights, although ignorance of what is in the HRA was profound as $70 \%$ of respondents could not name three of their rights.
} 
is that the Act has never been sufficiently 'owned' by British people as 'their bill of rights.' In my view three main factors account for this.

First, the HRA appeared like a bolt out of the blue to most people. Whereas years of local and national public consultation preceded bills of rights in Canada, New Zealand and South Africa in the 1980s and 1990s (and, more recently, in the Australian Capital Territories and the State of Victoria) there was no prior consultation in the UK. Very little groundwork was done to prepare for the introduction of the HRA beyond the publication of Bringing Rights Home, the discussion document Labour issued before it came to power and a large-scale training programme for the judiciary prior to the Act coming into force.

This has been compounded, until recently, by an absence of consistent political leadership and no statutory Human Rights Commission to explain the role and purpose of the HRA. Whilst the Act was always promoted as a means of 'bringing rights home', ${ }^{67}$ early references to it as a major constitutional innovation, acting as Britain's Bill of Rights, were soon buried. The more the HRA revealed its potency, the more the government seemed intent on playing down its significance, in the hopes it might wither away.

In 1998 Jack Straw described the HRA as 'one of the most important pieces of constitutional legislation the UK has seen'. ${ }^{68}$ Lord Irvine suggested it 'occupies a central position in our integrated programme of constitutional change'. ${ }^{69}$ But by 2002 ministers were insisting that 'the Act is primarily about access to justice in our own courts'.70 The accompanying narrative suggested this was no more than a 'tidying up' measure to complete the process that had begun in the 1950s with the ratification of the ECHR. For anyone who didn't much like anything with the title European in it, this was hardly a convincing selling point.

Second, the lack of a strong narrative about the HRA left the field wide open for the furtive imagination of the tabloids, in search of easy copy, to exploit with fervour. Once the inevitable reality dawned that the HRA, as a 'higher law', was far more potent than the 'bringing rights home' narrative suggested, the tabloid press had a field day, inventing stories based on cases that never happened or had little to do with the Act itself, with no government rebuttal unit, until recently, to counter these urban myths. ${ }^{71}$ The tabloids have effectively created a subtitle to the Act in the public's mind which reads: human rights for FTPs: foreigners, terrorists, and paedophiles - law abiding citizens need not apply.

Much of this is reminiscent of the media frenzy that accompanied the introduction of race and sex discrimination legislation in the 1970s. Time will tell

\footnotetext{
$67 \mathrm{~J}$. Straw and P. Boateng 'Bringing Rights Home: Labour's plan to incorporate the European Convention on Human Rights into UK law', Labour Party, December 1996.

${ }^{68}$ HC Deb vol 306 col 78216 February 1998.

${ }^{69}$ HL Deb vol 317 col 12273 November 1997.

${ }^{70}$ Beverley Hughes, Minister for Citizenship and Immigration, HC Deb vol 391 col 60428 Oct 2002.

71 In June 2006, for example, the tabloids ran a story for days about a suspected car thief, Barry Chambers, evading arrest on a roof, demanding his right to food and drink under the HRA. The police confirmed that this was a standard negotiating strategy to coax him off the roof but this did not stop the media repeating this apocryphal story, with no rebuttal from government.
} 
whether the Lord Chancellor's recently launched campaign - Human Rights are Common Sense - and the new Commission for Equality and Human Rights (CEHR), the first British statutory body charged with promoting the values in the HRA, will succeed in rehabilitating it. ${ }^{72}$

The third, and possibly most important reason why the HRA has failed to bed down smoothly, is that it has been rather too successful at challenging the executive for the government's comfort. In an inverse imitation of Frankenstein's monster, the Act's own creator has increasingly turned against it.

Many of the early predictions about clogged up courts and a new litigious culture did not materialise, at least not as a consequence of the HRA. Early research indicated that very few cases at any level were wholly reliant on the HRA. ${ }^{73}$ Then, as now, the HRA is mainly cited as a defence in criminal trials or as an additional argument in judicial reviews or civil cases.

If the world hadn't shifted on its axis after 11 September 2001 - less than a year after the HRA came into force - there is every reason to believe that by now it would have bedded down to become an accepted part of the legal and constitutional landscape of the UK. Instead the national and international preoccupation with domestic and global security meant that the HRA was tested in the most challenging of circumstances.

Once Britain threw in its lot with George Bush in the 'war on terror' after the terrible events of $9 / 11$, the Prime Minister and then Home Secretary, David Blunkett, rapidly became frustrated with judges that would not deport foreign suspects to a country where there was a real risk they would be tortured. This was blamed on the HRA even though the courts had been complying with this interpretation of ECHR Article 3, the prohibition on torture, since the 1996 case of Chahal, when the Conservatives were still in power. ${ }^{74}$

After the 2005 London bombings in particular, the Prime Minister sometimes sounded like a cheerleader for the tabloids' negative spin, threatening to 'amend the Human Rights Act in respect of the interpretation of the ECHR'.75 Amidst further warnings about the durability of the HRA, in May 2006 Tony Blair asked the Home Secretary, John Reid, and the Lord Chancellor, Charlie Falconer, to

\footnotetext{
72 The CEHR, due to operate from October 2007, will have a duty to clarify and promote the values in the HRA to both officials and the wider public. It is also mandated to champion the importance of human rights in general, like human rights commissions throughout the world. There will also be a separate Human Rights Commission for Scotland.

${ }^{73}$ See J. Raine and C. Walker, 'The Impact on the Courts and the Administration of Justice of the Human Rights Act 1998', October 2002, which found relatively limited impact of the HRA on the courts in terms of challenges and additional workload, although it had invoked a number of significant policy and practice changes and was felt to be engendering a stronger human rights culture within the courts.

74 Soering v UK 1989; Chabal v UK 1997. In times of national emergency states can usually 'derogate' from most provisions of the ECHR but this excludes the prohibition on torture which is why the government cannot legislate to require the courts to take national security considerations into account when adjudicating on deportations to countries where there is a risk of torture. The government is trying to persuade the European Court of Human Rights to change its mind on this by intervening in a Dutch case, Ramsy v Netherlands.

75 Prime Minster's statement on anti-terror measures, Press Conference, 5 August 2005
} 
review the impact of the HRA on their departments (through which the HRA was incidentally given a largely 'clear bill of health').

This was the political climate last June when the Leader of the Conservative Party, David Cameron, announced his intention to scrap the HRA (but not our ratification of the ECHR) and introduce what he called 'a modern British Bill of Rights to define the core values which give us our identity as a free nation'.76 Cameron repeated this commitment at his first party conference in October in a speech bereft of almost all other policies and it was reiterated in a House of Commons Debate on the Human Rights Act on 19 February. ${ }^{77}$

\section{QUESTION 3: HOW DO WE JUDGE THIS PROPOSAL TO INTRODUCE A BRITISH BILL OF RIGHTS? DO WE ASSUME THAT THINGS CAN ONLY GET BETTER; OR COULD THEY GET WORSE?}

The Cameron package received a mixed response. Some commentators and bill of rights campaigners welcomed it. ${ }^{78}$ Others of various political persuasions questioned its 'constitutional literacy'. ${ }^{79}$ Probably the most outspoken criticism came from within Cameron's own party. Ken Clarke, chair of the Conservative's Democracy Task Force, described the proposals as 'xenophobic' and 'legal nonsense'. 80

Is this fair? It is hard to deny that the Cameron package is shot through with legal confusion, if not nonsense. Were a British Bill of Rights to be weaker or more qualified than the ECHR, which appears to be what he wants, the UK government would fall foul of the Strasbourg court with increasing regularity. ${ }^{81}$ But if to avoid this, the Bill of Rights were broadly similar to the ECHR, the domestic courts would strive to iron out any differences by interpreting it to comply with the Convention as much as possible, as happens elsewhere in Europe.

\footnotetext{
76 n 25 above.

${ }^{77}$ HC Deb vol 457 col 6819 February 2007.

78 Peter Facey of Charter 88, for e.g. said: 'We welcome David Cameron's commitment...If he wants to protect citizens rights and ensure they cannot be infringed by any government he should start a nationwide debate on whether we should have a written constitution.' See 'Cameron's call to repeal legislation would not end deportation battles, say ministers', The Guardian, 27 June 2006. See also Professor Geraldine Van Bueren, letter to The Times, 5 September 2006.

79 'Cameron's plan to overturn rights laws labelled 'complete nonsense' Independent, 27 June 2006. See also Mary Ann Sieghart, The Times, 30 June 2006; Vernon Bogdanor, The Guardian 1 July 2006.

80 Quoted in The Guardian 29 June 2006.

81 This would be a reversal of recent years. The number of violations involving the British government has fallen since the effect of the HRA started to bite. See Review of the Implementation of the Human Rights Act, Department of Constitutional Affairs, July 2006 at [4]. The number of cases where at least one violation of the ECHR was found has fallen from 30 in 2002, when pre-HRA cases were still being heard, to 15 in 2005.
} 
Cameron's main pitch was that a home-grown Bill would encourage the ECtHR to back off and interfere less with 'British parliamentary sovereignty'. This is simply wrong. The suggestion that a less broad, more 'specific', bill of rights will 'protect' the UK from Strasbourg is a misreading of the Court's 'margin of appreciation' doctrine, as evidence from countries like France or Germany clearly demonstrates ${ }^{82}$. Cameron seems to have confused the Strasbourg's court 'margin of appreciation' doctrine, which applies when there is no European consensus on what minimum standards consist of, with the concept of subsidiarity, an EU term for retaining national 'independence', not applicable to notions of fundamental, universal human rights.

The main 'interference' Cameron wants freedom from is the prohibition on deporting foreign nationals to countries where there is a real risk they will be tortured. He has declared this to be the main purpose of repealing the HRA. 'It is time to replace the Human Rights Act with a British bill of Rights' Cameron wrote in the Sunday Times on 12 November, 'that will enable ministers to act within the law to protect our society. If M15 tells the government that a foreign national is... a danger to national security, then the home secretary should be free to balance the rights of the suspect with the rights of society... and proceed with the deportation if necessary.'

Someone needs to advise Mr Cameron that for as long as we remain within the Council of Europe or EU, and are therefore subject to the ECHR, a domestic Bill of Rights will provide no get out clause from the absolute prohibition on torture. ${ }^{83}$

As for the charge of xenophobia, this gets to the subtext of the Tory proposals. Cameron's argument is that the HRA simultaneously 'impacts on our ability to protect our society against terrorism' and fails to protect traditional British liberties like jury trial or free speech. His pledge to replace the HRA with 'a clear articulation of citizen's rights that British people can use in British courts' could be interpreted as no more than a soundbite to answer the tabloid charge that 'foreigners' are making use of 'foreign rights' in 'our' domestic courts. But his words have to be taken seriously. Cameron's reference to 'British People' claiming 'citizens rights' in 'British courts' is ambiguous but it appears to extend beyond the kind of rights that are enshrined to the people who can lay claim to them.

The underlying philosophy of human rights is, of course, that every human being is entitled to fundamental rights simply because they are human. British citizens who live and travel abroad protest if they are not treated according to internationally recognised standards. Whilst voting rights and many benefits are usually dependent on citizenship or residence, the fundamental rights in

82 In Germany, for example, the ECHR has the rank of a statute over which the constitution is supreme. However, the European Court of Human Rights does not apply the margin of appreciation any differently to Germany than any other state.

83 As we have seen, there are many areas where the European Court of Human Rights accepts that domestic courts are best placed to use their 'own discretion,' provided this does not weaken the baseline protection provided by the ECHR; but torture is not one of them. Alongside slavery it is one of the only rights to receive absolute and unqualified protection under the ECHR. 
democratic bills of rights generally apply to everyone within the jurisdiction of a state. The Bush government built the Guantanamo Bay detention centre for foreign nationals to bypass the natural justice protections of the American Constitution. The Conservative package hints at a Bill of Rights that would exclude non-citizens from certain of its provisions from the outset.

Some of the interest in the Cameron proposals stems from his flagging up the holy grail of 'entrenchment'. He has promised to explore ways of 'entrenching' a Bill of Rights; for example, by amending the Parliament Act so that the House of Commons could not amend or repeal the Bill without the support of the Lords.

This is an interesting idea, but parliamentary entrenchment to protect bills of rights from direct amendment or repeal should not be confused with judicial entrenchment to override legislation which indirectly amends it. Given that one of Cameron's stated purposes in repealing the HRA is to prevent 'highly dangerous criminals and terrorists' from 'trump[ing] the rights of the people of Britain to live in security and peace, ${ }^{34}$ it is difficult to imagine he will introduce a Bill that gives less control to Parliament than the HRA. The current 'dialogue model' is anyway not one any government is likely to alter significantly in adopting a domestic bill of rights, least of all a Conservative Party committed to retaining 'parliamentary sovereignty' and motivated to repeal the HRA because of the way it has been interpreted by the courts.

In the current climate, it is unlikely a Bill of Rights would even be on the political agenda if it were not for the precedent of the HRA, which no government is likely to pledge to repeal, nowadays, without suggesting a replacement. Any Bill of Rights that is going to take us further than where we are now would either have to consolidate the rights in the HRA or run alongside it. There is plenty of precedent for this. All 46 members of the Council of Europe have incorporated the ECHR into their law, through one means or another. ${ }^{85}$ At least 21 of these have their own bill of rights or written constitutions.

Of course there is a case to consult on additional rights that might supplement the HRA. This was, as we saw, original Labour Party policy and is currently underway in Northern Ireland. The Tories have suggested a British Bill of Rights should include issues like data protection which is inadequately protected by the HRA, or jury trial which is absent from it. 86 Their list is not large because the HRA includes all the standard rights present in bills of rights the world over. Other potential candidates for consultation could include a stronger equality clause, ${ }^{87}$ provisions from the Children's Convention,, 88 and carers' and

\footnotetext{
${ }^{84} \mathrm{n} 1$ above.

85 In states with a monist tradition, the rights in the Convention can be applied by domestic courts on ratification. In states with a dualist approach to international law, like the UK, the substantive rights must be incorporated by statute to become applicable in domestic law.

86 See in particular D. Grieve 'Liberty and Community in Britain' Speech for Conservative Liberty Forum, 2 October 2006.

${ }^{87}$ ECHR Article 14 is limited to outlawing discrimination in relation to the civil and political rights enshrined in the Convention and does not explicitly include categories like age, disability and sexual orientation, although the interpretation of Article 14 has increasingly included these groups.
} 
independent living rights from the new UN Convention on the Rights of Persons with Disabilities. ${ }^{89}$

Some campaigners suggest that this is the time to consult on including some of the social and economic rights that polls suggest are most popular. Many of these already exist in a variety of statutes, but have no special constitutional status, such as free education, access to health care free at the point of need and housing for the homeless. To guard against excessive individualism overriding the public interest, instead of legally enforceable, individual rights, the duty on the state would need to be expressed as the 'progressive realisation' of economic, social and cultural rights. The South African Bill of Rights provides a useful precedent for such a model.

As we have learnt to our cost, the process of consulting upon a bill of rights can be as important as the rights themselves. The strongest case for adopting a British Bill of Rights in this period of ongoing debate on our national identity is that we have no document with the equivalent symbolism of the American or South African Bills of Rights to turn to at times of national tension. ${ }^{90}$

A Bill of Rights can provide a unifying force in a diverse society, as the Conservative Party has suggested, but it will not do so if it ignores the contribution of many countries, and most cultures, to the human rights values recognised throughout the world today and turns its back on the international human rights treaties which virtually every modern bill of rights is based on. ${ }^{91}$

But it is easy to underestimate what is involved in a consultation process of this magnitude. It can be a long and difficult path. Henry Bellingham, Shadow Minister for Constitutional Affairs, hinted at this when he said in the recent parliamentary debate that 'the only answer is to repeal the Human Rights Act and consider introducing a new, modern Bill of Rights that can balance rights with responsibilities. ${ }^{92}$

Consider the word consider. Is Bellingham hinting that a consultation process of such complexity -on a bill of rights and responsibilities- could easily get bogged down in difficulties and divisions? Rightly or wrongly, that is why Labour avoided

88 The 1990 UN Convention on the Rights of the Child includes recognition of the 'rights and duties of parents.'

${ }^{89}$ At www.un.org/disabilities/convention/ (last visited 12 May 2007).

${ }^{90}$ Some commentators propose introducing a Bill of Rights and Responsibilities. E.g. J. Fisher, 'A British Bill of Rights and Obligations' (2006) Conservative Liberty Forum. The responsibilities which flow from rights can be set down in an interpretative preamble to emphasise the normative nature of human rights but very few bills of rights contain legally enforceable duties aimed at individuals. These are contained in a host of other statutes but the essence of bills of rights is to establish those rights to which all are entitled because of our common humanity and which are only limited to protect the rights of others or the wider community, not because some human beings are less 'deserving' than others.

${ }^{91}$ The UDHR reflects the insights and values of all major religions and cultures and many of these are reflected in the ECHR, in spite of its European designation. South African MP, Professor Kader Asmal, in a speech on the South African Constitution at Chatham House on 10 November 2006, warned that a 'shared vision of national identity' could, if based on a 'mythical past,' rather than the future, bring with it 'the alienation of many immigrants and communities' whose experience belies the 'imagining' of a Britain 'that has always held dear the values of liberty, tolerance and social justice.'

92 HC Deb vol 457 col 8019 February 2007. 
a widespread consultation process in the first place. Realistically, the HRA could be repealed as a first session measure whilst, whatever the intention now, the Conservative's proposed bill of rights may never see the light of day.

As Shami Chakrabarti, the Director of Liberty, has said, beware the perils of 'permanent constitutional revolution'. The really difficult challenge is not to perpetually seek for the promised land but to bed down what has already been achieved.

That means liberating human rights from the law courts and lawyers and returning them to where they came from; the struggles of people in their every day lives from abuse of power and their quest for equality, dignity and fair treatment. It means rebutting false stories; promoting good ones and speaking about human rights in plain English. It means working with grass roots campaigns and sometimes for unpopular causes, building common ground through the values we can all share.

Thomas Jefferson, the $3^{\text {rd }}$ president of the USA, once said 'a bill of rights is what the people are entitled to against every government on earth'. But it is worth remembering the words of another wise constitutionalist, Justice Learned Hand, who said: 'Liberty lies in the hearts of men and women; when it dies there, no constitution, no law, no court can save it'. Or as Alice might have said to the Mad Hatter: 'Yes it is possible to have less'. A Bill of Rights which is based - not on the principles of universal human rights - but on chauvinism and nationalism, would be much less than we have now. 